This item was submitted to Loughborough's Research Repository by the author.

Items in Figshare are protected by copyright, with all rights reserved, unless otherwise indicated.

\title{
Supporting Paralympic wheelchair sport performance through technological, physiological and environmental considerations
}

PLEASE CITE THE PUBLISHED VERSION

http://dx.doi.org/10.1080/03014460.2016.1234644

\section{PUBLISHER}

(C) Taylor \& Francis

\section{VERSION}

AM (Accepted Manuscript)

\section{PUBLISHER STATEMENT}

This work is made available according to the conditions of the Creative Commons Attribution-NonCommercialNoDerivatives 4.0 International (CC BY-NC-ND 4.0) licence. Full details of this licence are available at: https://creativecommons.org/licenses/by-nc-nd/4.0/

\section{LICENCE}

CC BY-NC-ND 4.0

\section{REPOSITORY RECORD}

Griggs, Katharine E., Victoria L. Goosey-Tolfrey, and Thomas A.W. Paulson. 2019. "Supporting Paralympic Wheelchair Sport Performance Through Technological, Physiological and Environmental Considerations". figshare. https://hdl.handle.net/2134/22595. 


\section{Supporting Paralympic wheelchair sport performance}

\section{K Griggs, V Goosey-Tolfrey \& T Paulson}

In 1948 Sir Ludwig Guttmann hosted the first wheelchair sport competition for the rehabilitation of World War II veterans at Stoke Mandeville Hospital. The Paralympic movement has subsequently undergone a remarkable growth as a platform for sport in individuals with a physical or intellectual impairment, both to enhance health and wellbeing and maximize physical potential. It has also provided a springboard for the promotion of social integration, accessibility in the built environment and awareness of disability rights. This September, Rio de Janeiro will see around 4,350 athletes from 176 countries compete for 528 medals in one of the largest multisport events in the world. The recent advancements in elite competitive performance at the Paralympics Games have been supported by the evolution of both evidence-based sports science and medicine support (Webborn \& Van de Vliet, 2012) and bespoke training/competition equipment (Burkett, 2010).

Wheelchair sports have been a prominent focus within the academic community due to the diversity of individual physiological impairments and the integrated unit formed by the athlete and their equipment. Optimal performance is the product of both hard work and training but also the configuration and maintenance of competition equipment. Adaptations to wheelchair design (wheel size, materials) and the wheelchair-user interface (bespoke moulded seating) allow athletes to customize equipment to their anthropometrics and the specific demands of their sport (Mason et al., 2013). Technology has also played a role in the development of player tracking equipment (indoor tracking system) to understand the movement demands of indoor wheelchair court sports (wheelchair rugby and basketball) for the prescription of specialised training programmes and player profiling (Rhodes et al., 2015). This technology has a multidisciplinary approach providing a greater understanding of players' roles and movement profiles on-court, but is also integral for creating evidence-based classification systems (Paulson \& Goosey-Tolfrey, 2016; Tweedy \&Vanlandewijck, 2011). Similarly to Olympic sport, technology has created some controversy within the Paralympic movement and thus an ongoing challenge is to determine whether the equipment represents "performance enhancement" or is "essential for performance."

Although many principles in training prescription are directly transferable from able-bodied guidelines, a consideration of the physiological consequences of an athlete's impairment is also important (Paulson \& Goosey-Tolfrey, 2016). For example, the loss of sympathetic innervation to the heart following a cervical spinal cord injury means typical heart rate based methods for quantifying training intensity in able-bodied athletes may often underestimate training loads/volumes. Therefore, subjective ratings of perceived exertion have been validated as a tool for monitoring training intensity and ensure athletes do not become over-trained in the lead up to major competitions (Paulson \& Goosey-Tolfrey, 2016). Current practice is often based on theory adapted from able-bodied guidelines, 
with a heavy reliance on anecdotal evidence and practitioner experience. Where possible this practitioner experience should be supplemented with impairment and sport-specific applied research.

With both Rio de Janeiro (2016) and Tokyo (2020) set to host the upcoming Paralympic Games, there is a large emphasis on athletes to prepare and adapt to potentially challenging environmental conditions, in addition to the added stresses of long haul travel. Logistics of travelling for any athlete can be stressful, but travel for wheelchair athletes requires greater planning to ensure specific needs are catered for and the risk of any medical complications is minimised. After four hard years of training it is imperative for the athlete to arrive at the Games as healthy as possible in order to compete at their peak. Upon arrival, the environment of the host city may be particularly demanding for wheelchair athletes with a spinal cord injury, who as a consequence of their impairment, have a reduced sweating capacity and disturbed redistribution of blood, leading to an increase in thermal strain. A unique and practiced approach regarding hydration and cooling is required to minimise this risk, particularly as small fluid losses imply a small amount of fluid replacement is required (GooseyTolfrey et al., 2015). An additional tool to combat the potentially challenging hot and humid environment of the next two Paralympic Games is the use of practical cooling strategies (ice vest, water sprays) to minimise the risk of heat illness (Griggs et al., 2015). Following methods employed by able-bodied athletes, the choice of strategy is dependent on the sporting regulations, practicality of the method and the nature and demands of the sport. Similar to the Olympic athlete, hydration and cooling strategies need to be considered on a case by case basis to maximise effectiveness and minimize disruption to the athlete.

Despite the growing interest in Paralympic sport, the evidence-base for supporting wheelchair sport performance remains limited, partly due to the small pool of heterogeneous athletes. A range of physical impairments demand a fully individualised approach in order to support wheelchair athletes and improve sporting performance through sport science, medicine and technology. The Rio de Janeiro 2016 Paralympics Games will once again provide an opportunity for Paralympic athletes to showcase their sporting prowess on a worldwide stage. The Paralympic movement should continue to grow with further developments in equipment and sport science and medicine support, all underpinned by sport-specific applied research. Despite challenges these individuals may have faced as a result of their impairment, their sporting performance at the Games will embody the Paralympic values of courage, determination, inspiration and equality.

\section{References}

1. Burkett B. 2010. Technology in Paralympic sport: Performance enhancement or essential for performance. Br J Sports Med 44:215-220.

2. Goosey-Tolfrey VL, Paulson TAW, Graham-Paulson TS. 2015. Practical considerations for fluid replacement in spinal cord injury. In: Meyer F, Szygula Z, Wilk, B editors. Fluid Balance, Hydration and Athletic Performance. Boca Ranton: CRC Press. 333p. 
3. Griggs KE, Price MJ, Goosey-Tolfrey VL. 2015. Cooling athletes with a spinal cord injury. Sports Med 45(1): 9-21.

4. Mason BS, Woude van der LHV, Goosey-Tolfrey. 2013.The ergonomics of wheelchair configuration for optimal performance in the wheelchair court sports. Sports Med 43(1):2338.

5. Paulson T, Goosey-Tolfrey V. 2016. Current perspectives on profiling and enhancing wheelchair court-sport performance. Int J Sports Physiol Perf. In Press.

6. Rhodes J, Mason BS, Perrat B, Smith MJ, Malone LA, Goosey-Tolfrey VL. 2015. Activity profiles of elite wheelchair rugby players during competition. Int J Sports Physiol Perf 10:318-324.

7. Tweedy SM, Vanlandewijck YC. 2011. International Paralympic Committee position standbackground and scientific principles of classification in Paralympic sport. Br J Sports Med 45:259-269.

8. Webborn N, Van de Vliet P. 2012. Paralympic medicine. Lancet 379:65-71. 